\title{
A Study on Performance of Outrigger Structural Systems during Lateral Loads on High Rise Structures
}

\author{
P. Purushotthama and Dr. Jagadish G. Kori
}

\begin{abstract}
The study focused on performance of outrigger structural systems during lateral loads on high rise structures. Linear static analysis of two buildings of 30 storey and 50 storey buildings for various models were examined using ETABS software, for Building without outrigger, building with core and outrigger system by bracings, building with core by shear wall and outrigger system by bracing, building with core and outrigger system by shear wall, building exterior panel and outrigger by shear wall. The analysis includes Lateral displacement, inter-storey drift and storey stiffness for Lateral loadings. From the results it is concluded that the effective performance of the structure will be obtained by building exterior panel and outrigger by shear wall at $15^{\text {th }}$ storey and top storey for 30 storey building and at $28^{\text {th }}$ storey and top storey for 50 storey building is found to be more effective.
\end{abstract}

Keywords--- Lateral Loads, Outriggers System, Tall Buildings, Linear-Static Analysis.

\section{INTRODUCTION}

$\mathrm{T}$ HE development of high rise structures and buildings are vigorously increased these years. People started to migrate from there natives or from villages to a metro-politian cities in search of jobs. Because of this metro-politian cities are becoming denser, i,e,. densely populated. As it is getting denser the availability of land becoming less and cost is also highly increasing. Hence to overcome these problems, high rise structures, multi-storey buildings are most prominent and effective solutions. For developing country like India and other countries, the high rise structures, multi-storey buildings are best option.

The structural system for high rise structures, buildings has undergone through dramatic changes and is been continuously emerging since decades. Structural system for high rise structures, buildings can be classified as two types.

a. Interior structures

b. Exterior structures

These are classified on the basis of lateral load resisting system. If the major load resisting system is in interior of the building then it is called interior system. Similarly, if outer

\footnotetext{
P. Purushotthama, PG Student, Department of Civil Engineering, Government Engineering College Haveri. Karnataka. E-mail:purucivil@gmail.com

Dr. Jgadish G. Kori, Prof. \& Head, Department of Civil Engineering, Government Engineering College Haveri, Karnataka, India. E-mail:korijg@gmail.com DOI:10.9756/BIJMMI.8148
}

perimeter of the building is load resisting, it is an exterior structural system. Outrigger Structural System Outriggers are firm horizontal structures or structural elements that are designed to improve structure, from overturning stiffness and strength by connecting the structure core or spine to the distant columns. Outrigger system has been used for narrow and tall buildings to provide better resistance against lateral loads. Behavior of outriggers for structures are simple, as the core of the structure is connected simply by a stiff arm to nearby columns or external columns. Analysis and design of outrigger structural system is not simple because relative stiffness depends on each structural element.

As the outrigger is connected between core and the exterior column, this will reduces over turning moment and efficiently reduces the lateral displacement of structure or building at the top. When the multi-storeyed buildings or skyscrapers are subjected to lateral loads, the exterior columns and the outrigger handle the rotation of the central core. Thus there is considerably reduce of lateral deflection and base moments, which would have arisen in free core building. Outrigger with core wall is as shown in Fig.1. Wind forces acting on core and core with outrigger structural system are as shown in Fig.2.

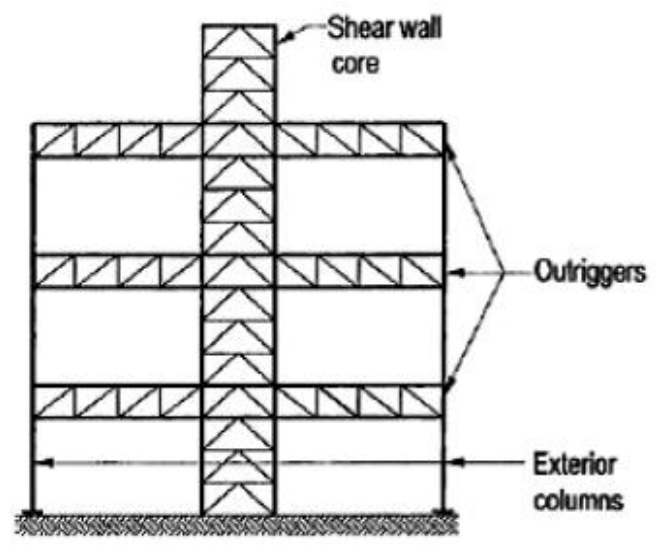

Figure 1: Outrigger with Core Wall 

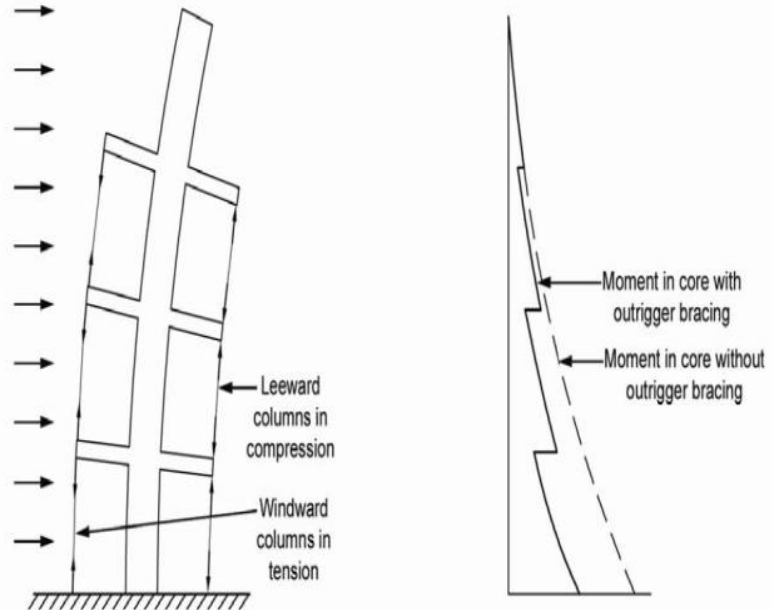

Figure 2: Core Supported Outrigger Structural System

The locations of outriggers have influence on the efficiency of the inter storey drift, storey stiffness and horizontal deflection in high rise multi-storey structures. An optimum outrigger location will be more effective in minimizing the lateral displacement and reducing storey drift, increasing storey stiffness, thus ensuring safety of structure subjected to horizontal loads.

\section{MODELLING OF STRUCTURAL BUILDINGS}

For the present study is taken with two buildings 3D models of 30 storey and 50 storey buildings.

The building further modeled for different types of structural elements combinations.

1. Building without outrigger.

2. Building with core and outrigger system by bracings (as shown in Fig.3.)

3. Building with core by shear wall and outrigger system by bracing (as shown in Fig.4)

4. Building with core and outrigger system by shear wall (as shown in Fig.5)

5. Building exterior panel and outrigger by shear wall (as shown in Fig.6)



Figure 3: Building with Core and Outrigger System by Bracings

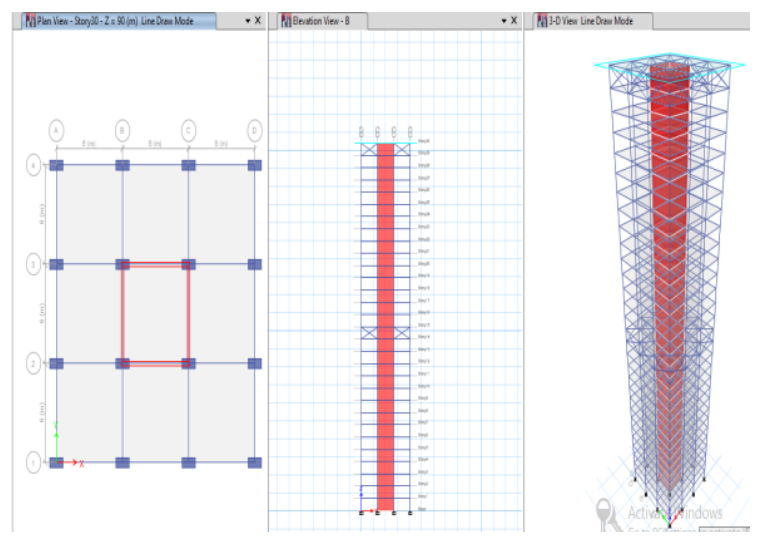

Figure 4: Building with Core by Shear Wall and Outrigger System by Bracing

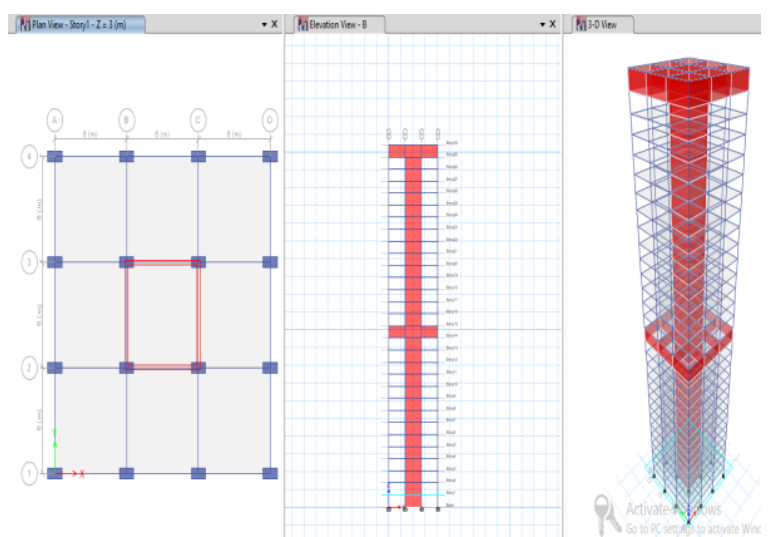

Figure 5: Building with Core and Outrigger System by Shear Wall

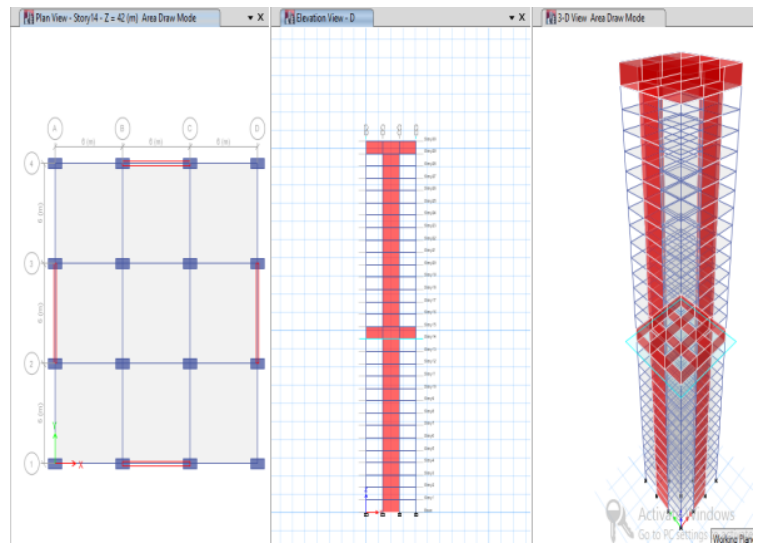

Figure 6: Building with Exterior Panel and Outrigger System by Shear Wall

The building has square plan dimensions of $18 \mathrm{~m} \times 18 \mathrm{~m}$, with 3 bays in X-direction and 3 bays along Y-direction; each bay is $6 \mathrm{~m}$ along both directions. The shear wall of $6 \mathrm{~m} \mathrm{x} 6 \mathrm{~m}$ is considered, the plan, elevation and 3D model view of the buildings are shown below. Typical storey height is $3 \mathrm{~m}$

Two outriggers are located with varying the position of outriggers. Firstly one outrigger is fixed at top storey, and by varying the position of second outrigger with the ratio of $\mathrm{H} / \mathrm{H} 1$ as shown in Fig.7 
Where

\section{$\mathrm{H}$ - Total height of the building}

H1- Height of the second outrigger from the base of the building

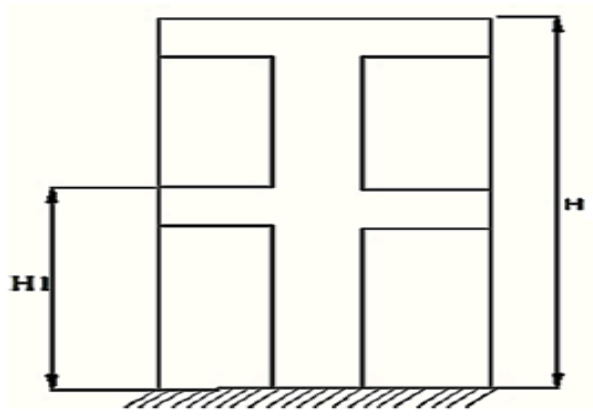

Figure 7: Relative Height of Outrigger

Following relative height of outrigger models are modeled and studied.

In 30 storeys building $\mathrm{H} / \mathrm{H} 1$ ratios;

a. Location of outrigger at storey 7 and $\mathrm{H} / \mathrm{H}_{1}=4.28$

b. Location of outrigger at storey 15 and $\mathrm{H} / \mathrm{H}_{1}=2$

c. Location of outrigger at storey 21 and $\mathrm{H} / \mathrm{H}_{1}=1.42$

In 50 storeys building $\mathrm{H} / \mathrm{H} 1$ ratios;

a. Location of outrigger at storey 7 and $\mathrm{H} / \mathrm{H}_{1}=7.14$

b. Location of outrigger at storey 14 and $\mathrm{H} / \mathrm{H}_{1}=3.57$

c. Location of outrigger at storey 21 and $\mathrm{H} / \mathrm{H}_{1}=2.38$

d. Location of outrigger at storey 25 and $\mathrm{H} / \mathrm{H}_{1}=2$

e. Location of outrigger at storey 28 and $\mathrm{H} / \mathrm{H}_{1}=1.78$

f. Location of outrigger at storey 35 and $\mathrm{H} / \mathrm{H}_{1}=1.43$

g. Location of outrigger at storey 42 and $\mathrm{H} / \mathrm{H}_{1}=1.19$

Consideration of Loads and Analysis

For static behavior purpose, the self-weight of the building i.e., dead load of building is considered and live load considered as $3 \mathrm{kN} / \mathrm{m}^{2}$, earthquake load is considered by confirming IS 1893(Part 1)-2002. The following parameters has been taken Zone $\mathrm{V}(\mathrm{Z}=0.36)$

Soil type as medium (Type II)

Importance factor as $(\mathrm{I}=1.5)$

Response reduction factor is $(\mathrm{R}=5)$

Time period $(\mathrm{T})$ is taken by software only as program calculated.

Analysis is done for different arrangement of outrigger braced and outrigger shear wall. Equivalent horizontal wind load confirming to IS 875(Part 3)-1987 the location selected as Bhuj, the following parameters are obtained.

The Terrain category $=2$

Structure class $=\mathrm{B}$

Basic wind speed $\mathrm{V}_{\mathrm{b}}=50 \mathrm{~m} / \mathrm{s}$

Risk coefficient $(\mathrm{k} 1$ factor $)=1.08$

Topography $(\mathrm{k} 3$ factor $)=1.28$

\section{RESULTS AND DISCUSSION}

\section{A. Building with 30 Storey}

Table 1: Comparison of Displacement of Building Due to eqx, from Without Outrigger System to with Outrigger System by Bracings at Different h/h1 Ratios

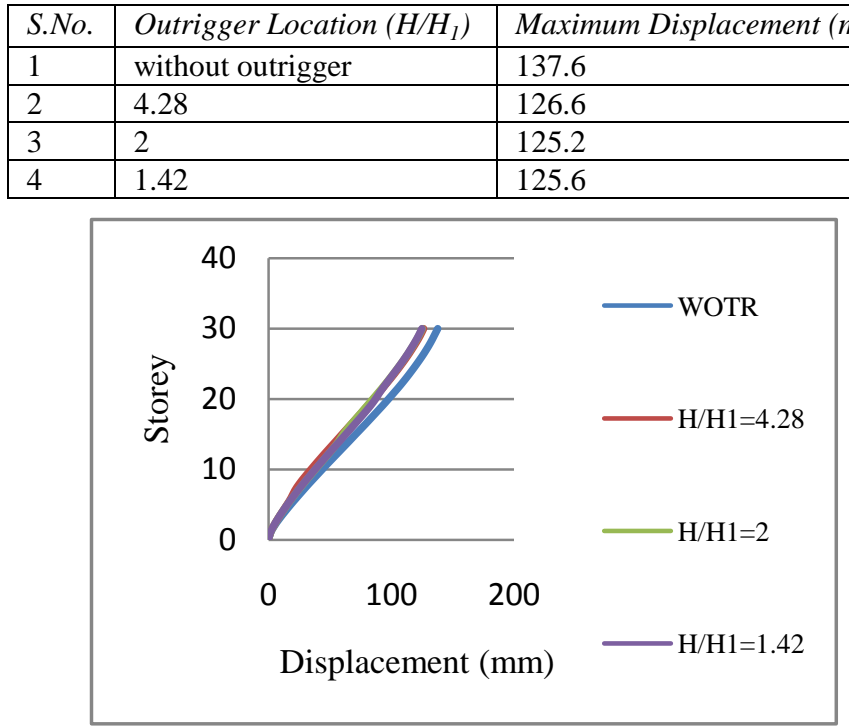

Figure 8: Variation of Displacement for Outrigger by Bracings at Different H/H1 Ratios and without Outrigger Due to EQ

Table 2: Comparison of Displacement of Building due to wind, from without Outrigger System to with Outrigger System by Bracings at Different H/H1 Ratios

\begin{tabular}{|l|l|l|}
\hline S.No & Outrigger Location $\left(\mathrm{H} / \mathrm{H}_{\mathrm{l}}\right)$ & Maximum displacement $(\mathrm{mm})$ \\
\hline 1 & without outrigger & 162.2 \\
\hline 2 & 4.28 & 127.8 \\
\hline 3 & 2 & 126.7 \\
\hline 4 & 1.42 & 129.5 \\
\hline
\end{tabular}

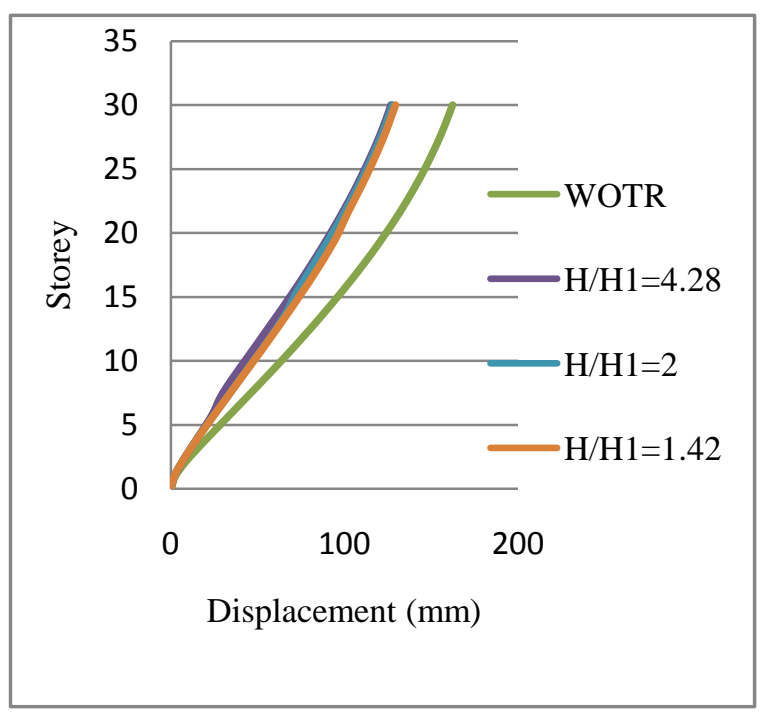

Figure 9: Variation of Displacement for Outrigger by Bracings at Different H/H1 Ratios and Without Outrigger Due to Wind 


\section{B. Building with 50 Storey}

Table 3: Comparison of Displacement of Building due to EQ, from without Outrigger System to with Outrigger System by Bracings at Different H/H1 Ratios

\begin{tabular}{|l|l|l|}
\hline S.No. & Outrigger location $\left(\mathrm{H} / \mathrm{H}_{\mathrm{l}}\right)$ & Maximum displacement $(\mathrm{mm})$ \\
\hline 1 & Without outrigger & 183.7 \\
\hline 2 & 7.14 & 170.4 \\
\hline 3 & 3.57 & 170.2 \\
\hline 4 & 2.38 & 170.1 \\
\hline 5 & 1.78 & 169.6 \\
\hline 6 & 1.43 & 169.9 \\
\hline 7 & 1.93 & 170 \\
\hline
\end{tabular}

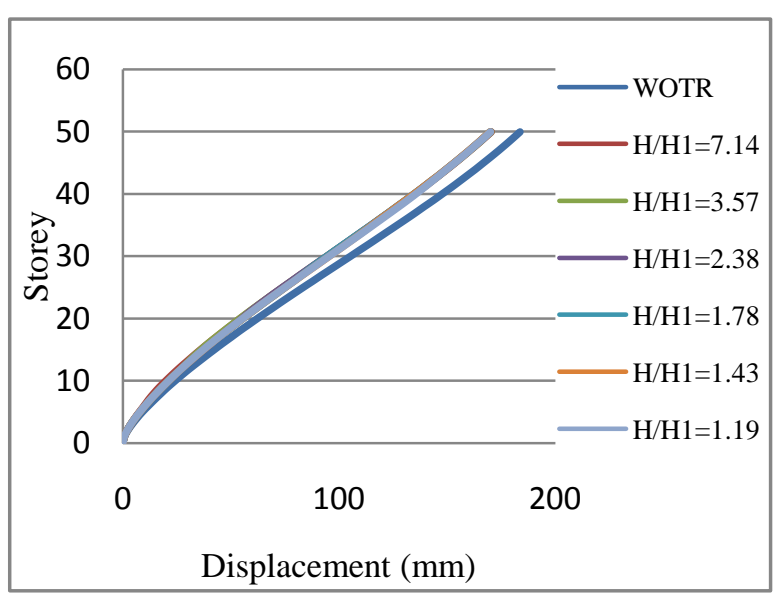

Figure 10: Variation of Displacement for Outrigger by Bracings at Different H/H1 Ratios and Without Outrigger Due to EQ

Table 4: Comparison of Displacement of Building Due to Wind, from without Outrigger System to with Outrigger

System by Bracings at Different $\mathrm{H} / \mathrm{H} 1$ Ratios

\begin{tabular}{|l|l|l|}
\hline S.No. & Outrigger location $\left(\mathrm{H} / \mathrm{H}_{1}\right)$ & Maximum displacement $(\mathrm{mm})$ \\
\hline 1 & Without outrigger & 363.1 \\
\hline 2 & 7.14 & 330.7 \\
\hline 3 & 3.57 & 329.9 \\
\hline 4 & 2.38 & 329.9 \\
\hline 5 & 1.78 & 329.3 \\
\hline 6 & 1.43 & 331.4 \\
\hline 7 & 1.93 & 332.2 \\
\hline
\end{tabular}

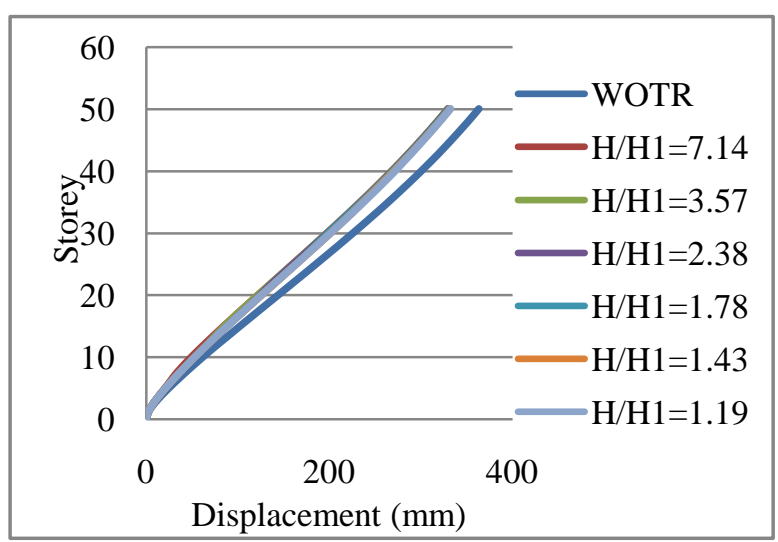

Figure 11: Variation of Displacement for Outrigger by Bracings at Different H/H1 Ratios and Without Outrigger Due to Wind
It is clearly observed that displacement in both 30storey and 50storey buildings due to earthquake load, values from Table:1\& Table:3, graph from Fig.4.1 \&Fig.4.3 respectively, reduction in maximum lateral displacement for building with core \& outrigger system with bracings to without outrigger, and is effectively reduced at the location $\mathrm{H} / \mathrm{H}_{1}=2$, i.e., outriggers at $15^{\text {th }}$ storey.

Also it is observed that the lateral displacement in both 30 storey and 50storey buildings due to horizontal load i.e., by wind load, values from Table 4.2, Table 4.4 and graphs from Fig.4.2, Fig.4.4 respectively, there is reduction in maximum horizontal displacement for building with core \& outrigger system with bracings to without outrigger, and is efficiently reduced at the location $\mathrm{H} / \mathrm{H}_{1}=2$, i.e. outriggers at $15^{\text {th }}$ storey.

The results of both earthquake loads and wind loads are proved, that the outrigger system for the building is considerably reduces the lateral movement i.e., lateral displacement of the building. The optimum location of the outrigger system to building is at $15^{\text {th }}$ storey that is $\mathrm{H} / \mathrm{H} 1=2$.

\section{Use of Different Structural Properties to Building Core and Outrigger System}

As already the optimum location of outrigger system to the building with 30 storey and 50 storey has been found. For the further study, models of building with different structural elemental properties in the core of building and outrigger system are been modeled.

Already we know the optimum location of outrigger system to the building, so now the modeling of different models are been done only for the optimum outrigger locations. The following models are modeled for the analysis. Then the results will be tabulated and compared with the graphs.

Following are the modeled with different types of structural elements combinations for outrigger system at location for the 30 storey and 50 storey buildings at $15^{\text {th }}$ floor $(\mathrm{H} / \mathrm{H} 1=2)$ and $28^{\text {th }}$ floor $(\mathrm{H} / \mathrm{H} 1=1.78)$ respectively.

1. Building without outrigger

2. Building with core and outrigger system by bracings

3. Building with core by shear wall and outrigger system by bracing

4. Building with core and outrigger system by shear wall

5. Building exterior panel and outrigger by shear wall 30 Storey Building 
Table 5: Comparison of Displacement due to EQ, for Different Combinations of Structural Elemental Properties to the Building and Outrigger System at $\mathrm{H} / \mathrm{H} 1=2$

\begin{tabular}{|l|l|l|l|}
\hline S.No & Type & $\begin{array}{l}\text { Maximum } \\
\text { displacement } \\
(\text { mm })\end{array}$ & $\begin{array}{l}\text { Reduction } \\
(\%)\end{array}$ \\
\hline 1 & $\begin{array}{l}\text { Building without } \\
\text { outrigger }\end{array}$ & 137.6 & - \\
\hline 2 & $\begin{array}{l}\text { Building with core and } \\
\text { outrigger system by } \\
\text { bracings }\end{array}$ & 125.2 & 9.01 \\
\hline 3 & $\begin{array}{l}\text { Building with core by } \\
\text { shear wall and outrigger } \\
\text { system by bracing }\end{array}$ & 118.8 & 13.66 \\
\hline 4 & $\begin{array}{l}\text { Building with core and } \\
\text { outrigger system by shear } \\
\text { wall }\end{array}$ & 111.8 & 18.75 \\
\hline 5 & $\begin{array}{l}\text { Building exterior panel } \\
\text { and outrigger by shear } \\
\text { wall }\end{array}$ & 105 & 23.69 \\
\hline
\end{tabular}

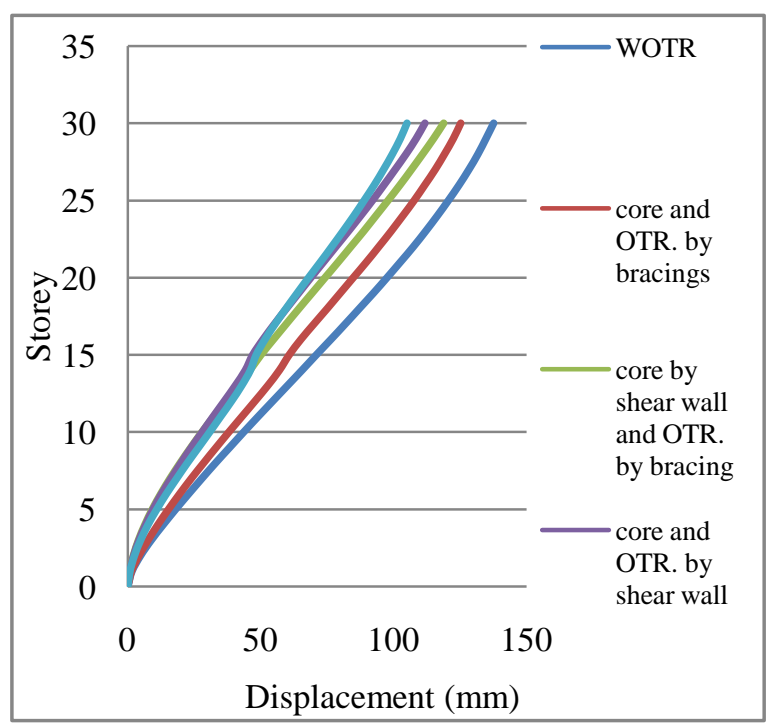

Figure 12: Comparison of Displacement from Different

Structural Property Combinations of Outrigger System Due to EQ

Table 6: Comparison of Displacement Due to Wind in, for Different Combinations of Structural Elemental Properties to the Building and Outrigger System at $\mathrm{H} / \mathrm{H} 1=2$

\begin{tabular}{|l|l|l|l|}
\hline S.No & Type & $\begin{array}{l}\text { Maximum } \\
\text { displacement } \\
(\mathrm{mm})\end{array}$ & $\begin{array}{l}\text { Reduction } \\
(\%)\end{array}$ \\
\hline 1 & $\begin{array}{l}\text { Building without } \\
\text { outrigger }\end{array}$ & 162.2 & - \\
\hline 2 & $\begin{array}{l}\text { Building with core and } \\
\text { outrigger system by } \\
\text { bracings }\end{array}$ & 127.8 & 21.21 \\
\hline 3 & $\begin{array}{l}\text { Building with core by } \\
\text { shear wall and outrigger } \\
\text { system by bracing }\end{array}$ & 92.7 & 42.85 \\
\hline 4 & $\begin{array}{l}\text { Building with core and } \\
\text { outrigger system by shear } \\
\text { wall }\end{array}$ & 80.3 & 50.49 \\
\hline 5 & $\begin{array}{l}\text { Building exterior panel } \\
\text { and outrigger by shear } \\
\text { wall }\end{array}$ & 75.4 & 53.51 \\
\hline
\end{tabular}



Figure 13: Comparison of Displacement from Different Structural Property Combinations of Outrigger System Due to Wind

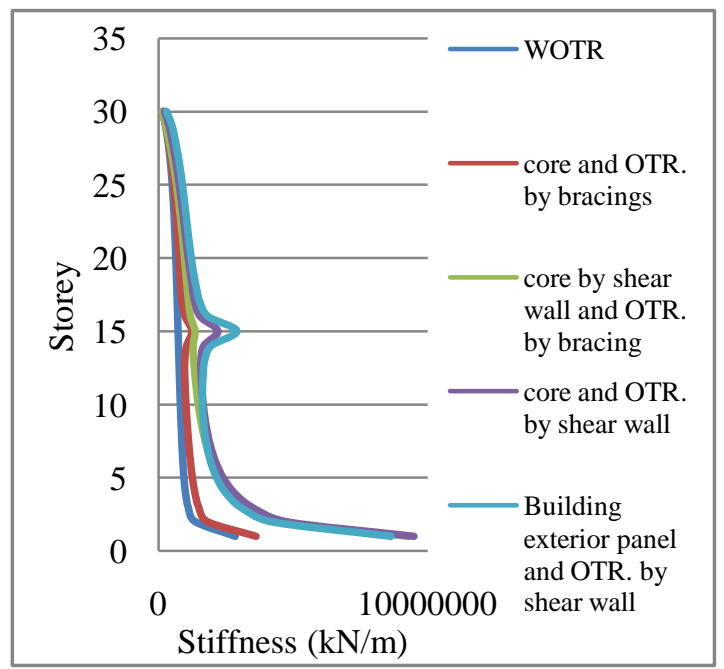

Figure 14: Comparison of Storey Stiffness from Different Structural Property Combinations of Outrigger System Due to EQ

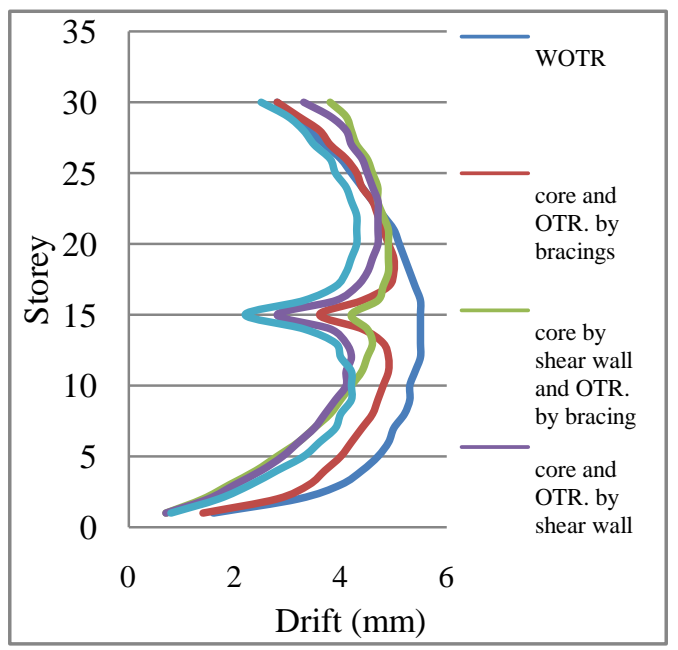

Figure 15: Comparison of Storey Drifts from Different Structural Property Combinations of Outrigger System Due to EQ 
Table 7: Comparison of Displacement Due to EQX, for Different Combinations of Structural Elemental Properties to the Building and Outrigger System at $\mathrm{H} / \mathrm{H} 1=1.78$

\begin{tabular}{|l|l|l|l|}
\hline S.No & Type & $\begin{array}{l}\text { Maximum } \\
\text { displacement } \\
(\mathrm{mm})\end{array}$ & $\begin{array}{l}\text { Reduction } \\
(\%)\end{array}$ \\
\hline 1 & $\begin{array}{l}\text { Building without } \\
\text { outrigger }\end{array}$ & 183.7 & - \\
\hline 2 & $\begin{array}{l}\text { Building with core and } \\
\text { outrigger system by } \\
\text { bracings }\end{array}$ & 169.9 & 7.51 \\
\hline 3 & $\begin{array}{l}\text { Building with core by } \\
\text { shear wall and } \\
\text { outrigger system by } \\
\text { bracing }\end{array}$ & 169.6 & 7.68 \\
\hline 4 & $\begin{array}{l}\text { Building with core and } \\
\text { outrigger system by } \\
\text { shear wall }\end{array}$ & 166.5 & 9.36 \\
\hline 5 & $\begin{array}{l}\text { Building exterior panel } \\
\text { and outrigger by shear } \\
\text { wall }\end{array}$ & 154.5 & 15.90 \\
\hline
\end{tabular}

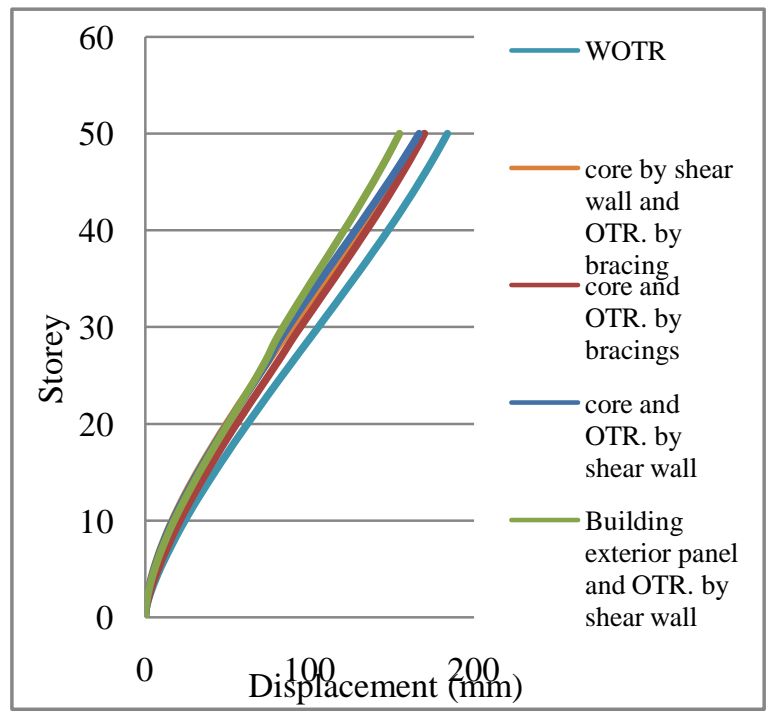

Figure 16: Comparison of Displacement from Different Structural Property Combinations of Outrigger System Due to EQ

Table 8: Comparison of Displacement due to wind, for Different Combinations of Structural Elemental Properties to the Building and Outrigger System at $\mathrm{H} / \mathrm{H} 1=1.78$

\begin{tabular}{|l|l|l|l|}
\hline S.No & Type & $\begin{array}{l}\text { Maximum } \\
\text { displacement } \\
(\mathrm{mm})\end{array}$ & $\begin{array}{l}\text { Reduction } \\
(\%)\end{array}$ \\
\hline 1 & Building without outrigger & 363.1 & - \\
\hline 2 & $\begin{array}{l}\text { Building with core and } \\
\text { outrigger system by } \\
\text { bracings }\end{array}$ & 330.9 & 8.87 \\
\hline 3 & $\begin{array}{l}\text { Building with core by } \\
\text { shear wall and outrigger } \\
\text { system by bracing }\end{array}$ & 279.1 & 23.13 \\
\hline 5 & $\begin{array}{l}\text { Building with core and } \\
\text { outrigger system by shear } \\
\text { wall }\end{array}$ & 265.9 & 26.77 \\
\hline 5 & $\begin{array}{l}\text { Building exterior panel and } \\
\text { outrigger by shear wall }\end{array}$ & 237.5 & 34.59 \\
\hline
\end{tabular}

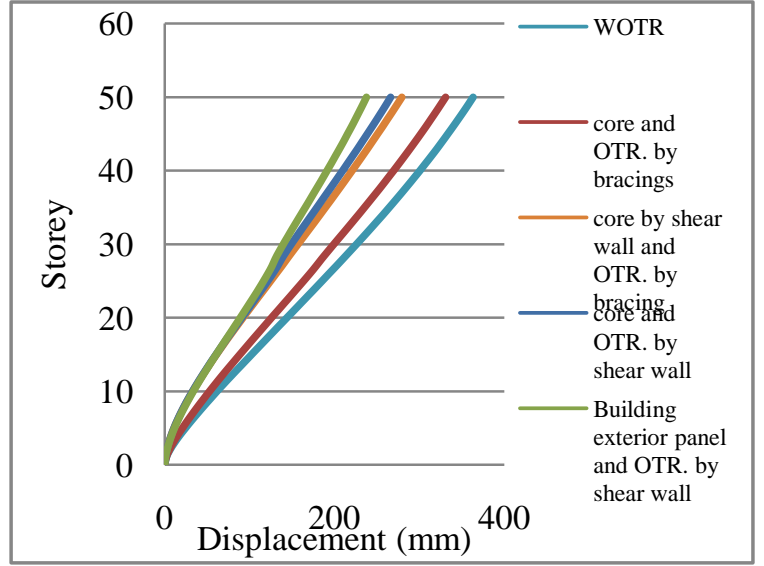

Figure 17: Comparison of Displacement from Different Structural Property Combinations of Outrigger System Due to Wind

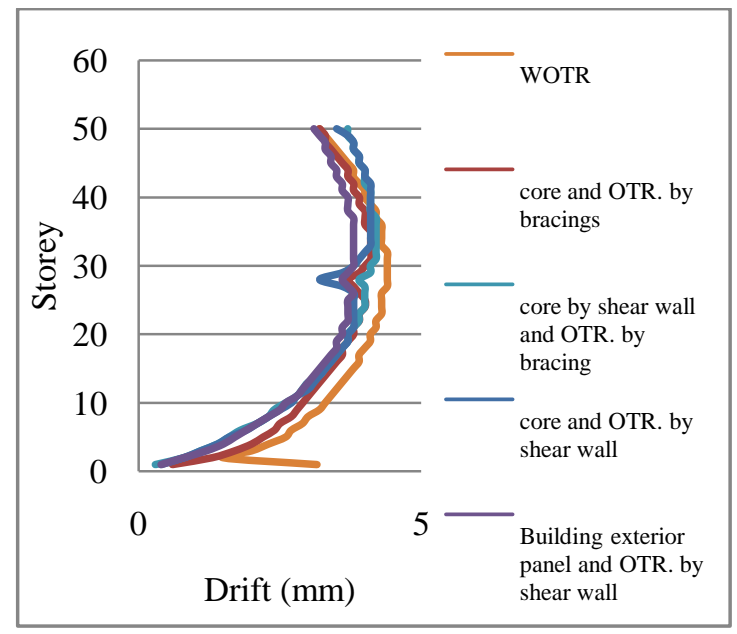

Figure 18: Comparison of Storey Drifts from Different Structural Property Combinations of Outrigger System Due to EQ

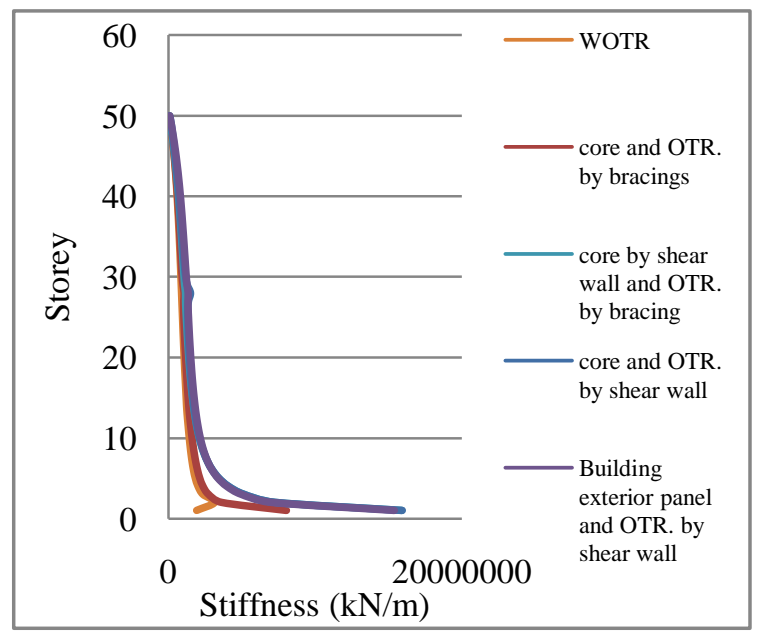

Figure 19: Comparison of Storey Stiffness from Different Structural Property Combinations of Outrigger System Due to $\mathrm{Eq}$ 


\section{SUMMARY AND CONCLUSION}

From the detailed study on performance of outrigger structural systems during lateral loads on high rise structures, of both 30 storey and 50 storey models following conclusions are arrived.

- Provision of outrigger structural system for high rise structures substantially increases structure stiffness and reduces lateral displacement, inter-storey drift against lateral loads, such as seismic i.e., earthquake and wind loads. The optimum location of outrigger structural system found to be for the buildings with

- $\quad 30$ storeys is at $\mathrm{H} / \mathrm{H} 1=2$ (outrigger by bracing at top and $15^{\text {th }}$ floor)

- 50 storeys is at $\mathrm{H} / \mathrm{H} 1=1.78$ (outrigger by bracing at top and $28^{\text {th }}$ floor)

- As per IS 1893(part 1)2002 for earthquake loads lateral displacement should be less than $\mathrm{H} / 250$ which is $360 \mathrm{~mm}$ and $600 \mathrm{~mm}$ for 30 storey and 50 storey buildings respectively. Using outrigger structural system there is considerable reduction in lateral displacement.

\section{For 30 Storeys Building}

- Maximum displacement without outrigger $=146.5 \mathrm{~mm}$

- Maximum displacement using building core and outrigger by bracing $=130.3 \mathrm{~mm}$

- Maximum displacement using building exterior panel and outrigger by shear wall $=107.3 \mathrm{~mm}$

- There will be reduction of $11 \%$ in lateral displacement using outriggers by bracings, where as in building exterior panel and outrigger by shear wall reduction is about $27 \%$

\section{For 50 Storeys Building}

- Maximum displacement without outrigger $=189.9 \mathrm{~mm}$

- Maximum displacement using building core and outrigger by bracing $=173.2 \mathrm{~mm}$

- Maximum displacement using building exterior panel and outrigger by shear wall $=155.7 \mathrm{~mm}$

- There will be reduction of $9 \%$ in lateral displacement using outriggers by bracings, where as in building exterior panel and outrigger by shear wall reduction is about $18 \%$

- As per IS 875(part 3)1987 for wind load maximum allowable lateral displacement is $1 / 500 \times \mathrm{H}$, that is $180 \mathrm{~mm}$ and $300 \mathrm{~mm}$ for 30 storey and 50 storey buildings respectively. Using outrigger structural system there is considerable reduction in lateral displacement.

\section{For 30 Storeys Building}

- Maximum displacement without outrigger $=190.4 \mathrm{~m}$

- Maximum displacement using building core and outrigger by bracing $=140.9 \mathrm{~mm}$

- Maximum displacement using building exterior panel and outrigger by shear wall $=79.5 \mathrm{~mm}$

- There will be reduction of $22 \%$ in lateral displacement using outriggers by bracings, where as in building exterior panel and outrigger by shear wall reduction is about $53 \%$

\section{For 50 Storeys Building}

- Maximum displacement without outrigger $=376.9 \mathrm{~mm}$

- Maximum displacement using building core and outrigger by bracing $=340.6 \mathrm{~mm}$

- Maximum displacement using building exterior panel and outrigger by shear wall $=242.2 \mathrm{~mm}$

- There will be reduction of $10 \%$ in lateral displacement using outriggers by bracings, where as in building exterior panel and outrigger by shear wall reduction is about $35 \%$

- As per IS 1893 (part-1): 2002 the inter-storey drift should not exceed 0.004 times the storey height, due to minimum specified design lateral load with partial load factor of 1 . That is $12 \mathrm{~mm}$ for both 30 and 50 storeys building. The maximum inter-storey drift out of two buildings found as $5.8 \mathrm{~mm}$.

- The increase in storey stiffness found out to be more for building exterior panel and outrigger by shear wall to without outrigger buildings. It is around 4.7 times and 2.6 times increase of storey stiffness for 30 storey and 50 storey buildings respectively. When compared with building exterior panel and outrigger by shear wall to without outrigger buildings.

\section{REFERENCES}

[1]. K. Kamath, N. Divya and A.U. Rao, "A study on static and dynamic behavior of outrigger structural system for tall buildings", Bonfring International Journal of Industrial Engineering and Management Science, Vol. 2, No. 4, Pp. 15, 2012.

[2]. Z. Bayati, M. Mahdikhan and A. Rahaei. "Optimized Use of MultiOutriggers System to Stiffen Tall Buildings", The 14th World Conference on Earthquake Engineering, Pp. 12-17, 2008.

[3]. P.S. Kian, "The use of outrigger and belt truss system for high-rise concrete buildings", Civil Engineering Dimension, Vol. 3, No. 1, Pp. 36, 2004.

[4]. R.J. Smith and M.R. Willford, "The damped outrigger concept for tall buildings. The Structural Design of Tall and Special Buildings, Vol. 16, No. 4, Pp. 501-517, 2007.

[5]. A. Vijay and S. Balachandar. "Feasibility Studies on the Use of Outrigger System for RC Core Frames", Copyrights@ 2012 Votrix Publication, Vol. 1, No. 3, 2012.

[6]. J.R. Wu and Q.S. Li, "Structural performance of multi-outrigger-braced tall buildings", The structural design of tall and special buildings, Vol. 12, No. 2, Pp. 155-176, 2003.

[7]. Hoenderkamp and Bakker, "Analysis of High-rise Braced Frame with Outriggers", The Structural Design of Tall Buildings and Structures, Volume 12, Page no.155-177, 2003.

[8]. A. Coull and W.O. Lau, "Analysis of multioutrigger-braced structures. Journal of Structural Engineering, Vol. 115, No. 7, Pp. 1811-1815, 1989.

[9]. IS (part 1):2002, "Provision on seismic Design of Buildings", Bureau of Indian standards, New Delhi, 1893.

[10]. IS 875(part 3), "Code of Practice for Design Loads (Other than Earthquake) for Buildings and Structures", Bureau of Indian Standards, New Delhi, 1987. 